\title{
FEDERALISM, POWER SHARING AND THE 2011 PRESIDENTIAL ELECTION IN NIGERIA
}

\author{
Emmanuel Remi Aiyede
}

\begin{abstract}
Power sharing has become a prominent feature of post-election conflict management practice in Africa in recent times. A study of the Nigerian experience provides useful lessons about the theory and practice of power sharing in a divided society with a federal system. Nigeria instituted the 'zoning with rotation' principle to shore up the affirmative action/federal character principle earlier devised to manage the inter-ethnic tensions that followed the crisis thrown up by the annulment of the presidential elections of 12 June 1993. This article examines the challenges and debates over power sharing in the build-up to the 2011 elections as a result of the entrance of Goodluck Jonathan (a southerner) into the presidential race, made possible by the death of President Umar Musa Yar'Adua (a northerner) in a clear upset of the power-sharing arrangement. It argues that while the 'zoning with rotation' principle remains useful for stability and representation in Nigeria its sustenance depends on its flexible application and the creativity of the elites as they negotiate and manage the power disequilibrium that results from perceived access or lack of access of segments of Nigerian society to top political office. The Nigerian case shows that the 'zoning with rotation' principle is problematic as a long-term solution because it constrains the notion of free political competition and the uncertain outcomes that are central to democracy.
\end{abstract}

\section{INTRODUCTION}

At the heart of the search for a solution to what Ayoade (1998, p 106) describes as 'representational equity' in Nigeria is the preference of the political elite for power sharing. Although this preference has underlined the series of federal innovations in Nigeria since independence, it has often been couched in the language of federalism. It is the crisis that followed the annulment of the 12 June 1993 presidential election that eventually removed the veil from this preference.

The introduction of the notions of 'power shift' and 'zoning with rotation' became important organising principles of politics in the Fourth Republic. While a lot has been written about federal character as a form of affirmative action in 
Nigeria, and its role in the electoral process has been recognised (Horowitz 1985), the notion of zoning, with an inherent principle of rotating public office, has not received serious intellectual attention. This is partly because the six geopolitical zones of North West, North East, North Central, South West, South-South and South East, which function as the framework for the allocation of the highest office in the land are not entrenched in the Constitution. Neither is the principle of rotation. Yet the use of federal character to provide the incentive for crossethnic mobilisation of votes and the resultant reward of moderate behaviour explicit in the 1979 and 1999 constitutions has been successful, largely due to the accompanying zoning and rotation principle.

The practice of 'zoning with rotation' came into its own in the democratic process in the Fourth Republic. Its salience was, however, challenged in the build-up to the 2011 general elections following the death of President Umar Musa Yar'Adua.

This article revisits the relationships among federalism, power-sharing and electoral systems as complementary frameworks of democratic governance. It examines the context, meaning and use of the 'zoning with rotation principle' as an important element of the democratic process in Nigeria and explores how it has functioned since the return to democratic rule in 1999, paying attention to the challenges it encountered as a result of the death of President Yar'Adua, a northerner, and his replacement by Goodluck Jonathan, a southerner.

It teases out the implications of the way in which the conflict over zoning was resolved for electoral competition and democracy in Nigeria and argues that zoning as an informal institution of power sharing effectively de-escalated the conflict that attended the annulled presidential election in 1993 and provided an effective framework for electoral competition afterwards. The zoning with rotation principle has, however, become problematic as a long-term principle of politics because it constrains the notions of free political competition and uncertain outcomes that are central to democracy.

The article suggests that the Nigerian case shows the important uses and limits of federalism with power sharing as a framework for political competition in a divided society. While zoning remains useful for stability and representation in Nigeria, its flexible application and the creativity of the elites is essential to success in dealing with the power disequilibrium that results from the perceived access or lack of access by segments of Nigerian society to top political office.

Given that power sharing has become a prominent feature of post-election conflict situations in Africa (especially in Liberia, Zimbabwe and Kenya) and elsewhere, a study of the Nigerian case provides useful lessons. In addition, it constitutes a valuable contribution to studies of power sharing that have been rekindled in post-conflict situations worldwide. 


\section{FEDERALISM, POWER SHARING AND ELECTORAL COMPETITION IN DIVIDED SOCIETIES}

The discourse on federalism focuses on the constitutional structure of the exercise of political authority and distribution of power among two or more layers of government. According to King (1982, p 77), 'federalism is an institutional arrangement, taking the form of a sovereign state and distinguished from other forms of state solely by the fact that its central government incorporates regional units in its decision procedure on some constitutionally entrenched basis'. Thus federalism deals with the problem of inclusion and representation in two ways in divided societies.

Firstly, the existence of at least two layers of government enables various sub-groups or territories to share power with the centre. Each sub-government has constitutionally guaranteed powers, responsibilities and sets of institutions. It is a form of limited government in which the various levels of government operate within a framework of checks and balances.

Secondly, sub-national units are incorporated into the process of decisionmaking at the centre. This is done not just by intergovernmental interaction or negotiations but also by ensuring that federal institutions are filled with representatives drawn from the various sub-units by means either of appointment or elections. Thus, federalism can provide a framework for power sharing and may have a direct effect on assembly size and district magnitude and, indeed, on electoral competition. However, when elections are viewed as a means of forming and changing democratic governments peacefully the focus is usually on electoral rules and the accompanying electoral systems.

There has been less than adequate theorising about federalism's role in the management of electoral competition. This is partly because federalism and electoral rules are viewed as two distinct mechanisms for restricting simple majority rule in managing societal conflicts.

However, federalism and electoral rules are sometimes linked by institutions of power sharing. For instance, consociationalism, as espoused by Lijphart $(1977,2002)$, provides a way of promoting power sharing or limiting the power of majorities in divided societies by means of four structural features. These are grand coalition government between parties from different segments of society; segmental autonomy, which is often distinguished from federalism; proportionality in the voting system and in public sector employment and minority veto.

Lijphart (1977) acknowledges that some particular environments are particularly appropriate for consociational democracy. These conditions include a balance of power among the segments, a multiparty system with segmental 
parties, some crosscutting cleavages, overarching loyalties, a representative party system, isolation of the segments from each other, and traditions of elite accommodation. Many of these conditions may be absent in many divided societies. Besides, a grand coalition does not apply effectively to a presidential system of government, where power is concentrated in a single office and segmental representation can only be achieved through rotation of the office.

To be sure, some scholars have suggested other forms of power-sharing arrangements that incorporate electoral systems with elements of power sharing in a federal and/or presidential system. Horowitz (1985), for instance, argues that democracy is possible in multi-ethnic states when government institutions are structured to encourage moderation and cooperation among different ethnic groups. This framework of centripetalism or integrative democracy provides institutions in which elected representatives have to work together before elections.

Such a network of institutions may include a presidential system and a semi-majoritarian electoral system which removes ethnic groups as organising principles of democracy and replaces them with a non-communal federal structure. Building on the work of Horowitz, Reilly (2001, p 11) emphasises three distinct element of centripetalism:

- the provision of electoral incentives for campaigning politicians to reach out to and attract votes from a range of ethnic groups other than their own;

- a bargaining arena, where political actors from different groups have an incentive to come together to negotiate and bargain in the search for cross-partisan and cross- ethnic vote-pooling deals;

- centrist, aggregative political parties or coalitions that seek multiethnic support.

The preoccupation with power sharing in relation to electoral systems is often focused on the conversion of votes to seats in Parliament and the way the various electoral systems affect electoral outcomes in terms of representation and inclusiveness. While parliamentary representation is important and provides a broader and more continuous access to power, for many ethnic or sub-national groupings in Africa, as elsewhere, the access to public office offered by permanent representation in Parliament does not seem to guarantee the group a sense of justice and security. The reason is that the arms of government are not perceived to provide an equal sense of belonging.

The difference in prestige between Parliament and the president, the presidency being the only single office that is elected directly by the whole 
country, further enhances the prestige of that office. ${ }^{1}$ Although there is a 'dual democratic legitimacy' of the two popularly elected independent organs there is a difference in prestige.

This is also the case to some extent in a parliamentary system where the prime minister is 'primus inter pares'. The visibility of the president or prime minister as the symbol of the nation makes access to that office symbolic of access to 'real power'. Indeed, the prominence of the executive arm as government in action and direct producer of public good, with the responsibility for actual disbursement of funds for these purposes and for patronage renders the executive offices more coveted and therefore election to those offices intensely competitive. That is why the outcome of presidential elections has been the basis for most post-election crises in Africa. In many of these post-election conflicts, power sharing, in which the incumbent retains dominance, has been the only way to avoid continued violence in the short term (Jarstad 2009).

While the intensity of electoral competition is often epitomised in elections to the office of president, in parliamentary systems the way the electoral system determines who becomes prime minister affects political mobilisation and interparty relations. In divided societies the ethnic origin of the president takes on special significance because access to that office is the most important assurance of inclusiveness.

Federalisation of national office by means of constituency delineation enables virtually every significant segment of society to have representation in Parliament. However, guaranteeing access by every segment of society to the office of president where demographic and other advantages favour a particular segment of society perpetually, or unduly exercising a monopoly over that office remains a challenge.

How each ethnic group or section of the country will access that office is therefore an important aspect of the debate about the role of electoral system design in promoting inclusivity and representation in a divided society and this has been a major issue in Nigeria. While recent discussions of power sharing in Africa have focused on government performance and accountability, the maintenance of post-election peace and the implications for electoral competitiveness (Levan 2011; Jarstad 2009; Doorenspleet 2005), this article makes an empirical contribution to the debate about the nature of the links among federalism, power-sharing and electoral systems in a bid to ensure inclusive representation and channel interethnic conflict into peaceful democratic competition in divided societies.

1 While this difference between the president and Parliament has been discussed in terms of political stability, there are no theories about its effect on the electoral system. 


\section{FEDERALISM AND POWER SHARING IN NIGERIA: THE ROAD TO ZONING WITH ROTATION}

In the build-up to independence the Willink Commission was set up to look into the question of domination of minorities by majority ethnic groups in the various regions, and a Bill of Rights was subsequently entrenched in the independence Constitution. However, two years later the guarantee of human rights proved to be insufficient to protect minorities and the structure of the federation was adjusted with the creation of the Mid-Western region in 1963.

As it turned out, several states would later be created for the same purpose and to defuse the intense struggle for power that, between 1967 and 1970, deteriorated into civil war. In other words, apart from the problem of minority protection caused by the fear of majority domination in the regions there was a fear that one section of the country would dominate the rest because each of the three regions at independence was the homeland of one of the three dominant ethnic groups: Hausa/Fulani, Yoruba and Igbo.

The Hausa/Fulani dominated the Northern Region, the Igbo the Eastern Region and the Yoruba the Western Region and the three groups were engaged in a fierce struggle for dominance of the country. Two elements of this struggle for dominance defined national politics in the First Republic and were reflected in the election crisis that created the environment for military intervention on 15 January 1966 and, ultimately, the descent into civil war.

The first element was that each of the three major political parties in the First Republic had strong base in one of the three regions and was thus ethnically based, a factor that led to fragile coalition governments. The second was that because the northern region was larger than the other two regions combined it was guaranteed the upper hand in democratic politics. It was always the major partner in any coalition and therefore became the dominant region and the most favoured in power-sharing arrangements, much to the distress of the other ethnic regions (Post \& Vickers 1973; Dudley 1973; Osaghae 1998).

The Northern People's Congress (NPC), in search of partners from the other regions, did not hesitate to deploy the enormous resources under its control as the party in government to enhance its electoral fortunes in those regions and tended to precipitate crises, especially during the general elections of December 1964 and the western regional elections of October 1965.

The structural imbalances cited above not only affected the stability of the federation, they were deepened by the killings that attended the coup d'état of 15 January 1966, largely led by Igbo officers. Tafawa Balewa, the prime minster, a northerner; Ahmadu Bello, the premier of the Northern Region, and Ladoke Akintola, premier of the Western Region, were among the major casualties. In the 
Eastern Region the coup plotters failed to carry out similar killings of political leaders, thereby raising the 'suspicion that the military were less "the trustees of the nation" than the instrument of the Igbo seeking to establish hegemony over peoples of Nigeria' (Panter-Brick 1970, p 26).

Although the coup was abortive, General Aguiyi Ironsi, an Igbo officer, became head of state and failed to bring the coup plotters to trial. There was a counter-coup by northern troops on 29 July 1966, during which General Ironsi and about 200 Igbo officers were killed. A stalemate attended the counter-coup when the military governor of the Eastern Region refused to recognise the new central government. The counter-coup was followed by a pogrom against Igbo residents in the Northern Region and the country descended into civil war, with declaration of the state of Biafra (Panter-Brick 1970; Post \& Vickers 1973; Dudley 1973; Osaghae 1998).

As part of the effort to prosecute the civil war and ensure Nigeria's territorial integrity the country was divided into 12 states, several of them created for minorities and splitting the major dominant ethnic groups into several units. Further measures were taken after the war to promote and extend power-sharing arrangements, especially when the country returned to civil rule in 1979. These measures included the further splitting of the country into 19 states and the stipulation in the 1979 Constitution of the observance of the federal character in appointments and election to public office, in the composition of the leadership of political parties and in the electoral formula. Indeed, the Constitution required a candidate to win not only the majority of YES votes over NO votes, he or she must record 'not less than one-quarter of the votes cast at the election in each of at least two-thirds of all states in the federation and the Federal Capital Territory'. According to s 134, where no clear winner emerges a run-off election must be held between the two highest-performing candidates. These provisions did not, however, eliminate ethnically based parties in the Second Republic (19791983). This was largely due to the presence of two leading politicians from the First Republic, Chief Obafemi Awolowo and Dr Nnamdi Azikiwe, who led two major parties and continued to draw followers largely from their ethnic bases. The persistence of ethnically based parties ensured that there was no decisive dominance of any party under the presidential system adopted in 1979. The second general elections, in 1983, were riddled with malpractice and misuse of the federal control of the police and ultimately provoked the coup of 31 December 1983.

Prolonged military rule further deepened the fear that one section of the country, the north, would become dominant. The reason was that the military governments were dominated by men and officers of northern extraction. All post-war military heads of government, with the exception of General Olusegun Obasanjo (1976-1979), were officers from the north. Although the establishment by 
General Ibrahim Babangida (1985-1993) of a two-party system served to promote more national parties, the annulment of the 12 June 1993 presidential election, won by chief Moshood Abiola of the Social Democratic Party (SDP), a Yoruba from the South, reversed the gains achieved by that process. The revolt that attended the annulment was the deepest crisis to have faced the country since the civil war. At the National Constitutional Conference of 1994/1995 power sharing became a major issue of debate as a way out of the impasse.

Inaugurating the conference, General Sani Abacha urged it 'to devise for our people a system of government, guaranteeing equal opportunity; the right to aspire to any public office, irrespective of state of origin, ethnicity or creed, and thus engender a sense of belonging in all our citizens' (Federal Republic of Nigeria - FRN -1995, p 3). The conference committee on power-sharing declared that 'the problem of power-sharing had been responsible for much of the tensions, emotions, conflicts, stresses and strains in most countries ...' and emphasised the need to evolve a 'power-sharing formula' based on Nigeria's historical experience (FRN 1995, p 143).

Several ideas, among them a rotational presidency, multiple vice-presidents and the creation of six geopolitical zones to facilitate the process of rotation of the limited number of public offices, were canvassed at the conference. Some of these ideas were accepted, others were not. The issue of a rotational presidency, the most controversial of the options (the South insisted on it while northern delegates opposed it), was only resolved by a consensus committee. The consensus committee brokered a broad concept of power sharing that included the rotation of the presidency, rotation of executive heads of government at state and local government level, zoning of public posts and proportional representation at all levels of government, and the establishment of the federal character commission to 'monitor and enforce federal character application and proportional representation in all aspects of our national life' (FRN 1995, pp144.145).

The committee on the executive observed that 'the election of the Nation's Number One Citizen has been a major source of political crises and upheaval' and agreed that the presidency should rotate between the North and the South. In the same spirit, the office of governor would rotate among the three senatorial districts of a state while chairmanship of a local government would rotate among the three sections into which each local government would be divided by the state electoral commission (see also Agbaje 1998).

Although this rotation principle was written into the 1995 Constitution it failed to find its way into the 1999 Constitution. Nonetheless, the principle was accepted by all three parties registered to participate in the transition to civil rule programme of the Abdulsalam Abubakar military government (1998-1999). Each of the political parties nominated a southerner of Yoruba extraction as its 
presidential candidate to underline the broad acceptance of 'power shift'. By 2002 the ruling People's Democratic Party (PDP) had reached a consensus that the presidency would go to the North after the tenure of President Olusegun Obasanjo. That agreement was to reassure Atiku Abubakar, then vice-president, and encourage him not to contest the PDP primaries against Obasanjo, who was making a bid for a second term.

The rotation and zoning principle was written into the party's constitution in 2009 (Akinbajo 2010). Article 7(2c) of the PDP constitution states that: 'In pursuance of the principle of equity, justice and fairness, the party shall adhere to the policy of rotation and zoning of party and public elective offices, and it shall be enforced by the appropriate executive committee at all levels.' Thus, since 1999, the broad acceptance of the rotation of vital public offices between the North and the South and among the six geopolitical zones and the allocation of appointed and elected offices in the same manner in the political parties and Parliament became the formula for realising the federal character principle stated in the 1979 and 1999 constitutions.

\section{THE OPERATION OF THE ZONING WITH ROTATION PRINCIPLE UNDER THE OBASANJO AND YAR'ADUA GOVERNMENTS}

During the first two terms of the Obasanjo government there was a fairly even distribution of the eight key national offices, to the extent that once the geopolitical zone of the president was determined the geopolitical origin of occupants of the other offices in the PDP and the government became, to an extent, predictable in terms of the available options. Table 1 contains a list of top national government and party offices, showing how they were distributed under the Obasanjo administration according to the six geopolitical zones. ${ }^{2}$

The president was from the south (South West), a concession granted after the 12 June crisis. The office of vice-president went to the North East, the office of Senate president to the South East and the offices of deputy speaker and secretary to the government of the federation to the South-South. The office of speaker of the House of Representative went to the North West, while those of deputy senate president and party chairman went to the North Central zone.

There was a slight change during the second term, when the office of deputy speaker moved from the South-South to the North East. Chibudom Nwuche and Ghali Umar N'Abba were not re-elected for the 2003-2007 National Assembly session. In all, the North and South each had four slots.

2 The offices included in the list are the eight top political offices often listed for distribution by the party and discussed in the media. 
The slight change in 2003-2007 led to a 3:5 ratio. The change was accounted for by the movement of the position of deputy speaker. The salience of the allocation system is in the fact that although several senate presidents were impeached during that period they were never replaced by their deputies. Instead, replacements were drawn from the South East, to which that office has been allocated. The same applied in the case of the speaker of the House and party chairman.

Table 1

Zoning of key offices under President Olusegun Obasanjo, 1999-2007

\begin{tabular}{|c|c|c|c|}
\hline Office & Name & $\begin{array}{l}\text { Geopolitical } \\
\text { zone }\end{array}$ & Remark \\
\hline President & Olusegun Obasanj & South West & 1999-2007 \\
\hline Vice-president & Abubakar Atiku & North East & 1999-2007 \\
\hline President of Senate & $\begin{array}{l}\text { Evan Ewerem } \\
\text { Chiba Okadigbo } \\
\text { Ayim Pius Ayim } \\
\text { Adolphus Wabara } \\
\text { Ken Nnamani }\end{array}$ & South East & $\begin{array}{l}\text { The first three were in } \\
\text { office consecutively } \\
\text { from 1999-2003. } \\
\text { The remaining } \\
\text { two were in office } \\
\text { consecutively from } \\
2003 \text { to } 2007\end{array}$ \\
\hline $\begin{array}{l}\text { Speaker of the } \\
\text { House }\end{array}$ & $\begin{array}{l}\text { Salisu Buari } \\
\text { Ghali Umar N'abba } \\
\text { Ahmed Bello Masari }\end{array}$ & North West & $\begin{array}{l}\text { The first two were in } \\
\text { office between } 1999 \\
\text { and } 2003 \text {. Masari } \\
\text { occupied the office } \\
\text { from } 2003 \text { to } 2007\end{array}$ \\
\hline $\begin{array}{l}\text { Deputy president } \\
\text { of Senate }\end{array}$ & Ibrahim Mantu & North Central & 1999-2007 \\
\hline Deputy speaker & $\begin{array}{l}\text { Chibudom Nwuche } \\
\text { Babangida Nguroje }\end{array}$ & $\begin{array}{l}\text { South-South } \\
\text { North East }\end{array}$ & $\begin{array}{l}1999-2003 \\
2003-2007\end{array}$ \\
\hline $\begin{array}{l}\text { Secretary to the } \\
\text { government of the } \\
\text { federation }\end{array}$ & Ufot Ekaette & South-South & $2003-2007$ \\
\hline Party chairman & $\begin{array}{l}\text { Solomon Lar } \\
\text { Barnabas Gemade } \\
\text { Audu Ogbe } \\
\text { Ahmadu Ali }\end{array}$ & North Central & $\begin{array}{l}1998-1999 \\
1999-2001 \\
2001-2005 \\
2005-2008\end{array}$ \\
\hline
\end{tabular}


During the tenure of President Yar'Adua (see Table 2) the presidency went to the north (North West). The office of vice-president was allocated to the South-South. The North Central got the office of senate president, while that of the Speaker of the House went to the South West. The office of Deputy Senate President and Party Chairman went to the South East. Similarly, when the speaker was impeached, the replacement was taken from the South West. The ratio of distribution between the north and south was even.

Table 2

Zoning of key offices under President Umar Musa Yar'Adua

\begin{tabular}{|l|l|l|l|}
\hline Office & Name & $\begin{array}{l}\text { Geopolitical } \\
\text { zone }\end{array}$ & \\
\hline President & Umar Musa Yar'Adua & North West & $2007-2010$ \\
\hline Vice-president & Goodluck Jonathan & South-South & $2007-2010$ \\
\hline $\begin{array}{l}\text { President of } \\
\text { Senate }\end{array}$ & David Mark & North Central & $2007-2011$ \\
\hline $\begin{array}{l}\text { Speaker of } \\
\text { the House of } \\
\text { Representatives }\end{array}$ & $\begin{array}{l}\text { Patricia Ette } \\
\text { Dimeji Bankole }\end{array}$ & $\begin{array}{l}\text { South West } \\
\text { South West }\end{array}$ & June -2007 \\
\hline $\begin{array}{l}\text { Deputy president } \\
\text { of Senate }\end{array}$ & Ike Ekwerenmadu & South East & 2011 \\
\hline $\begin{array}{l}\text { Deputy speaker } \\
\text { of the House of } \\
\text { Representatives }\end{array}$ & Usman Bayero Nafawa & North East & $2007-2011$ \\
\hline $\begin{array}{l}\text { Secretary to the } \\
\text { government of } \\
\text { the federation }\end{array}$ & $\begin{array}{l}\text { Baba Gana Kingibe } \\
\text { Party chairman }\end{array}$ & $\begin{array}{l}\text { Vincent Ogbulafor } \\
\text { OkwesiliezeNwodo }\end{array}$ & North East \\
\hline
\end{tabular}

Thus, the PDP's zoning with rotation power-sharing principle appeared settled and augmented the federal character principle that had been in place since 1999, which covers a broader field of distribution. However, when Yar'Adua's illness became severe and it was clear that he was not going to complete his four-year term, there was palpable fear that this balance would be upset. This was because, unlike in the case of impeachment by the National Assembly, where it is easy to 
replace the officers with people from the allocated zone, the Constitution provides that the vice-president should act as president where the president is unable to perform his functions. In this case, the president not only went to Saudi Arabia without formally handing over to the vice-president, certain members of the his 'kitchen Cabinet', with the support of his wife, kept his ill health secret.

President Yar'Adua was away for more than 80 days without giving due notice to the National Assembly and, unknown to the vice-president, was subsequently ferried into the country under cover of night and taken, with military support, from the airport to the presidential villa. This created a major stir in the polity until the National Assembly, submitting to pressure from civil society and with the support of the Governors' Forum, empowered the vice-president to act as president, drawing on what it called the 'doctrine of necessity'.

This was only achieved after three major decisions were reached to address the fear of the North that if Goodluck Jonathan became the substantive president he would not relinquish the position in 2011 to enable the North to complete the eight-year term to which it was entitled under the party's rotational presidency arrangement. The three decisions were:

- that the PDP's presidential candidate for 2011 would come from the North;

- that Goodluck Jonathan should become acting president;

- that preparations for the 2011 party primaries should begin immediately.

Agbo 2010, p 27

In time President Yar'Adua died and Goodluck Jonathan was sworn in as president in terms of the Constitution, putting the entire rotational arrangement in disarray and resulting in the fate of the power-sharing principle becoming the major issue in the build-up to the 2011 general elections.

\section{ZONING DEBACLE}

The controversy over Yar'Adua's successor in 2011 took on a sinister dimension when former President Olusegun Obasanjo, chairman of the Board of Trustees of the PDP, denied, in an interview with the Voice of America, that there was any zoning arrangement. Although Jonathan had not formally declared his intention to stand for president in 2011 when Obasanjo made the statement it was interpreted as an encouragement to him to do so.

Obasanjo's statement was contradicted by Vincent Ogbulafor (South East), then party chairman of the PDP, who stated that power must remain in the North 
until 2015, and former Senate president Ken Nnamani told Newswatch that s 7(2) (c) of the party's constitution recognised zoning and rotation.

As the controversy raged, Acting President Jonathan expressed no commitment to run. However, in an interview with CNN he maintained that he was not barred by any law from standing and said he was committed to ensuring a free and credible election in 2011. Subsequent efforts to effect changes in the leadership of the PDP were interpreted as a sign that Jonathan was working to take control of the party in order to clear the way for his emergence as a strong candidate in the PDP primaries.

Ogbulafor was accused of corruption, arrested and taken to court by the Economic and Financial Crimes Commission (EFCC) and 19 members of the PDP Reform Forum, led by former senate president Ken Nnamani (South East), who claimed to be working to promote democracy within the party, were suspended. Ogbulafor was eventually removed and replaced as party chairman by Ekwesilieze Nwodo, who immediately declared that zoning had only been used as a clear and firm principle in the party in 1999.

During that period Abubakar Rimi (North West), who had opposed the principle and applied to contest the presidential primary of the party, was prevented from doing so. Apart from this incident, said Nwodo, the party had not prevented or excluded any member from vying for any position, regardless of the person's zone of origin. The 1999 primaries had been contested by Obasanjo (South West) and former vice-president Alex Ekwueme (South East), who came from different zones in the South, even though the office was said to have been zoned for the South West. In 2003 Obasanjo had stood in the presidential primary against aspirants from the North West and North Central. The primaries in 2007 involved a contest among several aspirants from various zones (Onabanjo 2010, pp 21-22).

As these changes in the party continued, supporters of Goodluck Jonathan's candidacy in 2011 continued to mobilise public support by making statements and placing advertorials in national dailies. They made a concerted effort to reach out to northern politicians (especially the minorities of the North Central and the North East zones) to support their campaign. In the event, a variety of interpretations of s7 (2)(c) of the PDP's constitution emerged. There were arguments and negotiations that led to the peaceful conduct of the PDP primaries.

\section{The arguments and their proponents}

The Northern Summit Group (NSG), led by Solomon Lar, one of the founding fathers of the PDP and its first national chairman, was the major supporter of Jonathan's candidacy. This group accepted zoning as the party's power-sharing 
formula but maintained that the zoning policy was not a permanent arrangement, merely a formula used to stabilise the country in 1999.

According to Lar:

It was agreed that zoning should be adopted and the presidency conceded to the South, the South-West in particular, considering the annulment of the June 12, 1993 presidential election and the feelings of the people of that part of the country at the time ... it was not a permanent issue ... the PDP is to determine whether to continue with it or not.

Okocha \& Shiklam 2010

Similarly, Barnabas Gemade (North Central), former national chairman of the PDP, argued that:

zoning was meant to serve the necessities of a particular time ... the basis for zoning no longer exists, since access to the office of president can no longer be viewed as a preserve of a particular region as it was viewed following the annulment of the June 12, 1993 elections.

Okocha \& Shiklam 2010

To Samuel Ortom (North Central), former PDP national auditor, the zoning policy was not a rigid arrangement and the provision did not prevent Jonathan from contesting the election. The NSG therefore urged the leadership of the PDP 'to allow the supremacy of the Nigerian constitution to guide the conduct and the guidelines and regulations for the presidential primaries to elect our presidential candidate' (Okocha \& Shiklam 2010).

Atiku Abubakar (North East), former vice-president, a major advocate of the zoning arrangement, argued that the arrangement was settled and that if Jonathan decided to seek re-election it might lead to political instability in the country. His position was strengthened by the Northern Political Leaders Forum (NPLF) led by Adamu Chiroma, a former minister of finance, who insisted that a northerner must replace Jonathan in 2011 to complete the North's term in 2015. The NPLF issued a communique declaring that the North had contrived the zoning arrangement to facilitate southern access to the presidency and that the North was not pleased by the strident calls on Jonathan to contest the presidential election.

The group began a process of producing a northern consensus candidate who would defeat Jonathan in the PDP primaries. It shortlisted three northern presidential aspirants: Ibrahim Babangida, former military president; Atiku Abubakar, former vice-president and Aliyu Gusau, former chief security adviser 
to the president, and eventually declared Abubakar to be the North's consensus candidates for the primaries on 23 November 2010 (Adisa, Ibrahim \& Usigbe 2010, p 1). The group declared that the retention of the PDP zoning arrangement would guarantee the stability of the country and provide the assurance that all ethnic groups, including minorities, would have a fair share of power. The NPLF argued further that no section of the national Constitution outlawed zoning and rotation (Okocha \& Shiklam 2010, p 1).

As a result of disagreements over a common position for the North on the issue a vote was taken by the Northern Governors' Forum at its meeting in Kaduna on 27 July 2010, even though some of the governors represented the opposition All Nigeria People's Party (ANPP). Seven of the 17 governors in attendance at the meeting voted against zoning.

On 26 July 2010, at a Stakeholders' Forum, leaders of the South-South declared that Jonathan should contest the 2011 presidential poll. They emphasised

the incontrovertible position of the Nigerian Constitution that gives full rights to President Goodluck Ebele Jonathan, above all other considerations, to aspire to the position of president at the 2011 elections, more so as the zone, in spite of its enormous contributions to Nigeria's GDP, is yet to produce a President or Head of State in the 50 years of Nigeria's existence as a sovereign nation.

The News, 10 May 2010

The SSF therefore called on 'all other geopolitical zones, organisations, communities and constituencies to support this quest to deepen, widen and consolidate democracy by supporting Goodluck Jonathan for President' (The News, 10 May 2010).

Other arguments against zoning included the view that it is an undemocratic formula that promotes mediocre performance by elected persons, entrenches ethnic consciousness, and creates a situation that makes it impossible for public office to be occupied by the best, regardless of his or her geo-ethnic origin. Opponents believed the provision in the PDP constitution for zoning must be subordinated to the 1999 Constitution, which affirms the right of all citizens to stand as candidates for public office.

In an editorial on the subject Tell magazine (2010), which had earlier advised Jonathan not to stand, argued that

a beneficiary has the tendency to give allegiance to his zone, instead of looking at the country as his constituency. As a matter of fact most 
proponents of zoning lead the campaign because they expect that it will attract undeserved advantages and privileges to their area ... since the zoning system had not served the nation well why stick to it?

In a decision, made on 12 August 2010, the National Executive Committee of the PDP declared that President Jonathan had the constitutional right to run for president. The chairman of the party, Okwesilieze Nwodo, however, insisted that the party had not abandoned the zoning principle.

The misconception, accusations that PDP has abandoned zoning, is very far from the truth. When our president emerged, he chose a northern Muslim as his vice president; when the chairman resigned, he was replaced by another chairman from the South Eastern zone. Our Senate president, speaker, deputy senate president and deputy speaker are from different zones of the country.

Leadership, 13 August 2010, p 1

At a ceremony in Abuja on 18 September 2010 President Jonathan declared his intention to run and was immediately endorsed by 28 state governors of the PDP, including 15 of the 19 governors from the North (Oyebode 2010, p 8; Adisa, Muogbo, Samuel, Usigbe \& Alao 2010, p 4). The PDP's presidential primary was eventually held on 13 January 2011 at the Eagle Square, with three candidates standing: the northern consensus candidate, Atiku Abubakar; a female aspirant, Sarah Jubril, and Goodluck Jonathan. Jonathan won in the six geopolitical zones and the Federal Capital Territory. He also defeated Atiku Abubakar in 32 states, including Atiku's home state of Adamawa (see Table 3).

The poll proved to a large extent that there were no northern consensus candidates and that the PDP was strong enough to withstand the challenges that followed the disruption of the zoning principle by the demise of President Yar'Adua. Goodluck Jonathan proceeded with his campaign and eventually contested and won the presidential election.

The election, which was described by observers as an improvement on previous elections, was contested by 17 candidates. Of these, three were considered frontrunners. They were Mohammadu Buhari (Congress for Progressive Change - CPC), North West; Nuhu Rhibadu (Action Congress of Nigeria - ACN), North East, and Goodluck Jonathan (PDP), South-South. Jonathan won in five of the six states in the South West, all five states in the South East, all six states in the South-South, none of the six states in the North West, two of the six states in the North East and five of the six states in the North Central - a total of 23 states. He also won in the Federal Capital Territory. 
Table 3

Results of the PDP Presidential Primary 2010

\begin{tabular}{|l|c|r|r|r|}
\hline Zone & Jonathan & Atiku & Jibril & Total \\
\hline SW & 483 & 24 & 0 & 507 \\
\hline SE & 423 & 23 & 0 & 446 \\
\hline S-S & 615 & 9 & 0 & 624 \\
\hline NW & 422 & 365 & 0 & 787 \\
\hline NE & 301 & 155 & 0 & 456 \\
\hline NC & 356 & 172 & 1 & 529 \\
\hline FCT & 24 & 3 & 0 & 27 \\
\hline $\begin{array}{l}\text { Total state } \\
\text { delegates }\end{array}$ & 2624 & 751 & 1 & 3376 \\
\hline $\begin{array}{l}\text { Number of } \\
\text { states won }\end{array}$ & 32 & 5 & 0 & 36 \\
\hline Announced & 2736 & 805 & 1 & 3542 \\
\hline $\begin{array}{l}\text { Needed to } \\
\text { win }\end{array}$ & 1802 & & & \\
\hline
\end{tabular}

Source: Nigerian Tribune, 14 January 2011, p 1

The total vote for Jonathan was 22495187 (58.89\%), while Buhari won 12214 853 (31.98\%) and Ribadu 2079151 (5.41\%). Jonathan won the majority vote and $25 \%$ of the votes in at least 31 states of the federation, complying with s 134 of the 1999 Constitution, which requires the president to win the majority vote and $25 \%$ of the votes in at least 24 states (see table 4 ).

Table 4

Jonathan's Performance in the 2011 Presidential Election

\begin{tabular}{|l|l|l|l|l|}
\hline States & Majority vote & $\mathbf{2 5 \%}$ & Zone & $\begin{array}{l}\text { No of registered } \\
\text { voters }\end{array}$ \\
\hline Lagos & Yes & Yes & South West & 14296163 \\
\hline Ogun & Yes & Yes & & \\
\hline Oyo & Yes & Yes & & \\
\hline Osun & No & Yes & & \\
\hline Ondo & Yes & Yes & & \\
\hline Ekiti & Yes & Yes & & \\
\hline
\end{tabular}




\begin{tabular}{|c|c|c|c|c|}
\hline States & Majority vote & $25 \%$ & Zone & $\begin{array}{l}\text { No of registered } \\
\text { voters }\end{array}$ \\
\hline Kaduna & Yes & Yes & \multirow[t]{7}{*}{ North West } & \multirow[t]{7}{*}{19803689} \\
\hline Katsina & No & No & & \\
\hline Kano & No & No & & \\
\hline Kebbi & No & Yes & & \\
\hline Sokoto & No & Yes & & \\
\hline Jigawa & No & Yes & & \\
\hline Zamfara & No & No & & \\
\hline $\begin{array}{l}\text { Cross } \\
\text { River }\end{array}$ & Yes & Yes & \multirow[t]{6}{*}{ South-South } & \multirow[t]{6}{*}{9474427} \\
\hline Delta & Yes & Yes & & \\
\hline Rivers & Yes & Yes & & \\
\hline Bayelsa & Yes & Yes & & \\
\hline $\begin{array}{l}\text { Akwa } \\
\text { Ibom }\end{array}$ & Yes & Yes & & \\
\hline Edo & Yes & Yes & & \\
\hline Abia & Yes & Yes & \multirow[t]{5}{*}{ South East } & \multirow[t]{5}{*}{7577212} \\
\hline Enugu & Yes & Yes & & \\
\hline Anambra & Yes & Yes & & \\
\hline Imo & Yes & Yes & & \\
\hline Ebonyi & Yes & Yes & & \\
\hline Adamawa & Yes & Yes & \multirow[t]{6}{*}{ North East } & \multirow[t]{6}{*}{10749059} \\
\hline Bauchi & No & No & & \\
\hline Borno & No & No & & \\
\hline Gombe & No & Yes & & \\
\hline Taraba & Yes & Yes & & \\
\hline Yobe & No & No & & \\
\hline Kwara & Yes & Yes & \multirow[t]{6}{*}{ North Central } & \multirow[t]{6}{*}{10684017} \\
\hline Kogi & Yes & Yes & & \\
\hline Nasarawa & Yes & Yes & & \\
\hline Benue & Yes & Yes & & \\
\hline Plateau & Yes & Yes & & \\
\hline Niger & No & No & & \\
\hline Abuja & Yes & Yes & FCT & \\
\hline
\end{tabular}

Source: Table created by author, with figures provided by INEC 
The announcement of the outcome of the election was greeted with violence in Kano, Kaduna, Borno, Yobe, Gombe and Niger states, in which Jonathan had not won the majority vote. The violence led to the postponement of gubernatorial elections in those states by two weeks.

With the election of the president and the imminence of the inauguration of the National Assembly, the PDP decided to review the zoning formula. According to the new formula adopted by the party's enlarged National Caucus on 2 May 2011, the Senate presidency was zoned for the North Central, signalling the reemergence of Senator David Mark as senate president, the speaker of the House was given to the South West - Muraina Ajibola (PDP, Oyo) was endorsed by the party. The position of party chairman was allocated to the North East zone, while the office of secretary to the Government of the Federation (SGF) was zoned for the South East. The South East also got the position of deputy senate president, while North East got the office of deputy speaker. The office of president has gone to the South-South zone, while the North West has the position of vice-president.

However, the new allocations were opposed by individuals and groups within the party. Those dissenting emphasised the need to observe several criteria beyond the need for geographical balance. These included the need to recognise the place of seniority in the National Assembly, a criterion on which the election of the leadership of Parliament is based. Another is the need to promote free choice by Parliament in place of party imposition of individuals, as there were diverse preferences regarding the selection of candidates.

Thirdly, there was the question of regional contribution to the party's performance in the polls. The South East felt that, in view of its contribution to the party's success in the polls, it should be rewarded with the position of speaker of the House of Representatives rather than the office of secretary to the Government of the Federation, which one member of the party described as 'a mere tea server in the federal Cabinet'. Lastly, there were those, especially from the northern zones, who completely discounted the zoning arrangement, arguing for the superiority of merit or for the zoning arrangements to be ignored in the case of the presidential primary (Ifoh 2011).

The dissention proved to be significant when, contrary to the zoning formula provided by the party, members of the House of Representatives elected Ibrahim Aminu Tambuwal (North West) and Emeka Nkem Ihedioha (South East) as speaker and deputy speaker respectively. The party leadership initially issued a statement rejecting Tambuwal as speaker, but it had to approach its members in the National Assembly to redress the imbalance with the allocation of other positions in a manner that would ameliorate the imbalance arising from disregarding the zoning principle. Consequently, the South-South was allocated the majority leader's positions in the Senate and House of Representatives, the North East 
got the Senate chief whip position and the South West the House's chief whip position. Similar allocations were made in respect of the chairmen of the standing committees of the National Assembly (Olatunji, Segun, Adisa \& Ajayi 2011).

The zoning arrangement for the eight top positions in government is shown in Table 5.

Table 5

Zoning under Goodluck Jonathan's Presidency

\begin{tabular}{|c|c|c|c|}
\hline Office & Name & Geopolitical zone & \\
\hline President & Goodluck Jonathan & South-South & 2011 to date \\
\hline Vice-president & Namadi Sambo & North West & 2011 to date \\
\hline $\begin{array}{l}\text { President of the } \\
\text { Senate }\end{array}$ & David Mark & North Central & 2011 to date \\
\hline $\begin{array}{l}\text { Speaker of } \\
\text { the House of } \\
\text { Representatives }\end{array}$ & $\begin{array}{l}\text { Ibrahim Aminu } \\
\text { Tambuwal }\end{array}$ & North West & 2011 to date \\
\hline $\begin{array}{l}\text { Deputy president } \\
\text { of the Senate }\end{array}$ & Ike Ekweremadu & South East & 2011 to date \\
\hline $\begin{array}{l}\text { Deputy speaker } \\
\text { of the House of } \\
\text { Representatives }\end{array}$ & Emeka Nkem Ihedioha & South East & 2011 to date \\
\hline $\begin{array}{l}\text { Secretary to the } \\
\text { Government of } \\
\text { the Federation }\end{array}$ & Ayim Pius Ayim & South East & 2011 to date \\
\hline Party chairman & $\begin{array}{l}\text { Mohammed Bello } \\
\text { Abubakar Baraje } \\
\text { Bamangar Tukur }\end{array}$ & $\begin{array}{l}\text { North West } \\
\text { North West } \\
\text { North East }\end{array}$ & $\begin{array}{l}2010-2011 \\
28 \text { July 2011-24 } \\
\text { March } 2012 \\
\text { 24 March 2012- } \\
\text { date }\end{array}$ \\
\hline
\end{tabular}

Thus, the current situation does not favour the South West and the North East zones. This is partly because of the disregard for the zoning formula and partly because of the poor performance of the PDP in the South West zone in the 2011 election. Before the election the South West was interested in the office of Senate president but most of the senate seats were won by the ACN and the Labour Party. Similarly, the North East was affected by the rule of seniority, which made it unacceptable for Mohammed Danjuma Goje, put forward by the zone, for the office of Senate president. These imbalances were corrected when Bamanga Tukur, from the North East, became party chairman and Olagunsoye Oyinlola, 
from the South West, became national secretary of the PDP on 24 March 2012 at the party's national convention.

\section{CONCLUSION}

Nigeria has adopted a complex power-sharing arrangement in which elements of power sharing straddle federalism and electoral systems in order to guarantee broad representation, cross regional collaboration in the appeal for votes and, particularly, to ensure that all segments of society feel they have guaranteed access to the number one position in government.

This framework could be defined as federal character and zoning with rotation. While power-sharing principles have evolved since the 1960s, the federal character principle was introduced in 1979 and the zoning with rotation principle emerged out of the post-12 June 1993 presidential election annulment negotiations. The power-sharing arrangement was essentially responsible for stability in Nigeria in spite of the poor conduct of electoral administration between 1999 and 2007.

It was, however, upset by the death of President Yar'Adua and the interest of Goodluck Jonathan, his vice-president, in standing for the presidency before a president from the North had completed two four-year terms, as set out by the power-sharing principle. The fact that the PDP presidential primary and the presidential election did not end in grave political polarisation shows that the power-sharing arrangement is flexible enough to blunt the sharp NorthSouth divide, reflecting the capacity of the Nigerian system to manage electoral competition. This has been made possible partly by the creativity of politicians, the long experience of cross ethnic and cross regional interaction promoted by the federal framework, as reflected in party organisation and the electoral formula and the zoning with rotation principle that has liberalised access to the office of president by means of 'power shift'.

Previous state reorganisation, as Suberu (2010) has observed, has transformed the arenas that groups and parties can dominate as springboards to power, thereby promoting greater proportionality in the relationship between ethnic group size and electoral strength. The national spread required by the electoral formula has also promoted the inter-ethnic alignments and coalitions that facilitated moderate behaviour in the conflict over the entrance of Goodluck Jonathan to the presidential race. This was shown in the constant effort to adjust the zoning arrangements and in the voting pattern revealed by the results of the 2011 presidential election. However, the debates and controversies that dogged the choice of candidate and the violence that greeted his victory show that the powersharing zoning with rotation principle remains a problematic formula in the effort to transform democracy into a system of limited or provisional victories. 


\section{- REFERENCES}

Adisa, T, H Ibrahim \& L Usigbe. 2010a. 'Consensus: North Picks Atiku'. Nigerian Tribune, 23 November.

Adisa, T, M Okey, S Idowu, L Usigbe \& N Alao. 2011b. ‘2011: Abuja Stands still for Jonathan'. Nigerian Tribune, 9 September.

Ado-Kurawa, I. 2005. Nigerian Politics and National Political Reform Conference. Kano: Tellettes Publishing House

Akinbajo, I. 2010. 'PDP Confronts Zoning Arrangement'. Next, 16 May.

Agbaje, A. 1998. 'The Ideology of Power-sharing: An Analysis of Content, Context and Intent'. In K Amuwo, A Agbaje, R Suberu \& G Herault (eds). Federalism and Political Restructuring in Nigeria. Ibadan: Spectrum Books.

Agbo, A. 2010. 'The Plot Against Jonathan: Yar'Adua's Kitchen Cabinet Consolidates the Plot to Frustrate Jonathan and Strengthen Their Hold on Power Ahead of the 2011 Elections'. Tell 10, 15 March.

Aiyede, E R. 2005. 'Leadership and the Pro-Democracy Movement in Nigeria'. In O Adebayo, A Agbaje, A Hussaina \& C Obi (eds). Beyond the State: Nigeria's Search for Positive Leadership. Ibadan: Ibadan University Press.

Ajero, C. 2010. 'The Zoning Debate'. Newswatch, 30 May.

Ayoade, J A A. 1998. 'The Federal Character Principle and the Search for National Integration'. In K Amuwo, A Agbaje, R Suberu and G Herault (eds). Federalism and Political Restructuring in Nigeria. Ibadan: Spectrum Books.

Doorenspleet, R. 2005. 'Electoral Systems and Good Governance in Divided Countries'. Ethnopolitics 4(4).

Dudley, B J. 1973. Instability and Political order: Politics and Crisis in Nigeria. Ibadan: Ibadan University Press.

Federal Republic of Nigeria. 1995. Report of the Constitutional Conference Containing the Resolutions and Recommendations volume II. Abuja: National Assembly Press.

Ifoh, O. 2011. 'PDP Ratifies Zoning'. National Mirror, 12 May.

Horowitz, D L. 1985. Ethnic Groups in Conflict. Berkeley, CA: University of California Press.

Jarstad, A K. 2009. 'The Prevalence of Power-Sharing: Exploring the Patterns of Post-Election Peace'. Africa Spectrum 44(3).

King, P. 1982. Federalism and Federation. London: Croom Helm.

Leadership. 2010.'President Jonathan gets Green Light from PDP', 13 August.

Levan, C A. 2011. 'Power-sharing and Inclusive Politics in Africa'. Governance: An International Journal of Policy, Administration and Institutions 24(1).

Lijphart, A. 1977. Democracy in Plural Societies: A Comparative Exploration. New Haven: Yale University Press. 
Lijphart, A. 2002. 'The Wave of Power-sharing Democracy'. In A Reynolds (ed). The Architecture of Democracy: Constitutional Design, Conflict Management and Democracy. Oxford: Oxford University Press.

News, The. 2010. 'The Zoning Controversy'. Lagos, 10 May.

Nigerian Tribune. 2011. 'PDP Presidential Primary: Jonathan wins, Defeats Atiku in Adamawa, other states, Says, I am agent of change, Nwodo excused from PDP convention', 14 January.

Okocha, C \& J Shiklam. 2010. 'Northern Summit Wants Four More Years for Jonathan'. ThisDay, 16 July.

Olatunji, S, J Segun, T Adisa \& A Ajayi. 2011. 'NASS Posts: PDP Ratifies New Zoning Arrangement'. Nigerian Tribune, 13 June.

Onabanjo, D. 2010. 'Navigating the Zoning Landmine'. Tell, 26 July.

Osaghae, E E. 1998. Crippled Giant: Nigeria Since Independence. London: C Hurst $\&$ Co.

Oyebode, O. 2010. 'What the Governors said, and failed to say'. The Nation, 19 September.

Panter-Brick, S K. 1970. ‘From Military Coup to Civil War, January 1966 to May 1967'. In S K Panter-Brick (ed). Nigerian Politics and Military Rule: Prelude to the Civil War. London: Athlone Press, University of London

Post, K W J \& M Vickers. 1973. Structure and Conflict in Nigeria 1960-65. London: Heinemann.

Reilly, B. 2001. Democracy in Divided Societies: Electoral Engineering for Conflict Management. Cambridge: Cambridge University Press.

Sisk, T D. Power-sharing and International Mediation in Ethnic Conflict. Washington, DC: United States Institute of Peace Press.

Suberu, R. 2010. 'The Nigerian Federal System: Performance, Problem and Prospects'. Journal of Contemporary African Studies 28(4).

Tell. 2010. 'Editorial: Why Jonathan Should not Run', 10 May. 